\title{
Short Communication \\ Synergistic Efficacy of Antibiotics and Silver Nanoparticles Synthesized from Eichhornia crassipes
}

\author{
S. Basker \\ Department of Biotechnology, Nandha Arts and Science College, Erode- 638052. \\ Tamil Nadu, India \\ Present Address: Department of Botany, Government Arts College (Autonomous), \\ Salem-636 007 \\ Corresponding author Email: biobasker@gmail.com
}

The increasing prevalence of bacterial resistance has made an important public health issue in the present scenario. Thus it is urging to develop alternate and more effective therapeutic strategies to treat both Gram-negative and Gram-positive microbes. Now a days silver nanoparticles (AgNPs) synthesized biologically gaining much importance with different applications as they are nontoxic and eco-friendliness. The antimicrobial activity of biosynthesized silver nanoparticles synthesized from aqueous extracts of Eichhornia crassipes was evaluated with the panel of antibiotics like vancomycin, penicillin, streptomycin and tetracycline and microorganisms in the category of either gram positive or gram negative type. E. coli and $S$. aureus proved to be effective with highest zone formation. In addition, possible synergistic effects of antibiotics were loaded with standard concentration of $20 \mu 1$ of AgNPs and the effect of inhibition was highest in the antibiotic Tetracycline followed by Streptomycin, Vancomycin and Penicillin with different tested microbes. The synergistic association of antibiotics with biosynthesized metallic silver nanoparticles proved to be effective against the tested microbes than control. The antibiotics showed higher zone of inhibition when added to AgNPs.

Keywords: Eichhornia crassipes, silver nanoparticles, Microorganisms

Antibiotics that work today may not work tomorrow. It is essential to investigate newer drugs to which there is lesser resistance (Sarkar et al., 2003). As resistance to old antibiotics spreads, the development of new antimicrobial agents has to be expedited if the problem is to be contained. However, the past record of rapid, widespread emergence of resistance to newly introduced antimicrobial agents indicates that even new families of antimicrobial agents will have a short life expectancy (Coates, 2002).
Today, silver is re-emerging as an important antimicrobial for the treatment of different microorganisms. Silver is one of the most universal antimicrobial substances (Russel, 1994; Raveendran, 2003). Clinicians have returned to silver wound dressings containing varying level of silver (Chopra, 2007; Gemmell, 2006). Ionic or nanoparticles form has a high antimicrobial activity and is therefore widely used for various sterilization purpose including materials of medical devices and water sanitization and has been used for years in the medical field for antimicrobial 
applications and Silver nanoparticles can be used to prevent HIV binding to host cells (Elechiguerra, 2007). Previously many works sited on synergistic action of antibiotics with some plant extracts like Tetracycline with Tectona grandis and two antibiotics like penicillin and tetracycline with the leaf and stem extracts of Salvadora persica (Purushotham et al., 2010 and Ahmed et al., 2010) respectively. In the way of nanotechnology, many researchers demonstrated the green synthesis of silver nanoparticles including bacteria, actinomycetes, fungi and plants. The plant materials have been successfully used for silver nanoparticles synthesis, due to their potential medicinal property, huge availability, and faster rate of synthesis.

The steadily increasing bacterial resistance to existing drugs is a serious problem, and therefore there is a dire need to search for new classes of antibacterial substances, especially from natural sources. Recently, several studies have indicated that AgNPs may strengthen the antibacterial effects of antibiotics against both susceptible and resistant bacteria, either additively or synergistically. Synergism is defined as a positive interaction created when two agents are combined and together they exert an inhibitory effect that is greater than the sum of their individual effects. In the present investigation, a biosynthesized silver nanoparticle from the weed Eichhornia crassipes was impregnated on standard antibiotic discs and their antibacterial potentiality was evaluated.

\section{Materials and Methods}

The target strains used for screening antibacterial activity were procured from Microbial Type Culture Collection Centre, Chandigarh, India and maintained in the Department of Biotechnology, Nandha Arts and Science College, Erode, Tamil Nadu. The bacterial strains like Escherichia coli MTCC 1698, Staphylococcus aureus MTCC 3160, Klebsiella pneumoniae MTCC 10309, Enterococcus Sp. MTCC 9728 and Bacillus cereus MTCC 430 were sub-cultured and 24 hours grown cultures were used for antimicrobial activity.

Fresh plants of Eichhornia crassipes was collected from water bodies from different locations of Erode district, Tamil Nadu and the collected samples were pooled together. The collected plants were washed with tap water to remove the debris and nanoparticles were synthesized biologically. The biologically synthesized silver nanoparticles from Eichhornia crassipes were used for the synergistic action with different antibiotic discs.

Disc Diffusion method was adopted according to the method of Kirby Bauer Method (1966). To determine the synergistic effects, each antibiotic disc $30 \mathrm{mcg}$ per disc (Streptomycin, Vancomycin, Penicillin and Tetracycline) was impregnated with $20 \mu \mathrm{l}$ of freshly prepared AgNPs and placed on the sterile Nutrient agar plates inoculated with test organisms. Standard antibiotic discs were used as control. These plates were incubated overnight at $37^{\circ} \mathrm{C}$. After incubation, the results were recorded by measuring the diameter of inhibition zone ( $\mathrm{mm}$ ) using measuring scale. The assay was performed in triplicates and tabulated.

\section{Results and Discussion}

In the present investigation, antimicrobial property of silver nanoparticles were performed with different types of antibiotics such as Penicillin, Streptomycin, Tetracycline, Vancomycin and its synergistic action were analyzed using disc diffusion method and reported in the table 1. Earlier, similar studies were performed by Thangapandiyan, (2016). In the present study, among four different antibiotics tried, tetracycline proved to be effective followed by streptomycin, vancomycin and pencillin. The activity could be determined as Tetracycline> Streptomycin> Vancomycin $>$ Penicillin. Among the five different bacterial organisms tried, AgNPs alone impregnated on sterile discs against Escherichia coli and Staphylococcus aureus 
proved to be best with higher zone formation which served as a control. The zone of inhibition is slightly lower than the antibiotics tried in the present study. Silver nanoparticles might attach to the surface of the cell membrane disturbing permeability and respiration functions of the cell. Smaller particles having the large surface area available for interaction would give more bactericidal effect than the larger particles (Kvitek et al., 2008). It is also possible that silver nanoparticles not only interact with the surface of the membrane, but can also penetrate inside the bacteria (David et al., 2008). Further, silver nanoparticles can cause damage to bacterial cells by interacting with DNA, proteins and other phosphorus- and sulfurcontaining cell constituents (AshaRani, Mun, Hande, and Valiyaveettil, 2009; Marambio- Jones \& Hoek, 2010; Nel et al., 2009). Finally it release silver ions, generating an amplified biocidal effect, which is size- and dose-dependent (Liu et al., 2010).

Table: 1. Synergistic antimicrobial efficacy of silver nanoparticles with different antibiotics

\begin{tabular}{|c|c|c|c|c|c|c|c|c|c|c|c|}
\hline \multirow[b]{2}{*}{$\begin{array}{l}\text { S. } \\
\text { No. }\end{array}$} & \multirow[b]{2}{*}{$\begin{array}{l}\text { Category } \\
\text { of } \\
\text { Microbes }\end{array}$} & \multirow[b]{2}{*}{ Test Microbes } & \multicolumn{9}{|c|}{ Zone of Inhibition (in $\mathrm{mm}$ ) } \\
\hline & & & 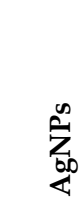 & 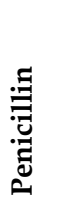 & 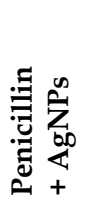 & 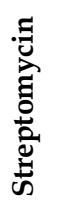 & 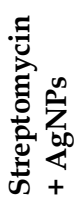 & 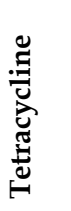 & 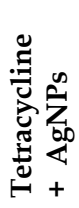 & 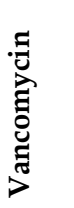 & 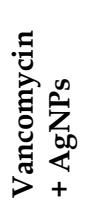 \\
\hline 1 & \multirow{2}{*}{$\begin{array}{l}\text { Gram } \\
\text { Negative } \\
\text { Bacteria }\end{array}$} & $\begin{array}{l}\text { Klebsiella } \\
\text { pneumonia } \\
\text { (MTCC } 10309\end{array}$ & 9.0 & 10.0 & 13.0 & 21.0 & 25.0 & 24.0 & 27.3 & 16.0 & 17.3 \\
\hline 2 & & $\begin{array}{l}\text { Escherichia coli } \\
\text { (MTCC 1698) }\end{array}$ & 12.0 & 12.0 & 13.0 & 21.3 & 24.6 & 23.6 & 24.0 & 15.5 & 18.6 \\
\hline 3 & \multirow{3}{*}{$\begin{array}{l}\text { Gram } \\
\text { Positive } \\
\text { Bacteria }\end{array}$} & $\begin{array}{l}\text { Bacillus cereus } \\
\text { (MTCC 430) }\end{array}$ & 11.0 & 13.0 & 13.3 & 21.6 & 24.6 & 19.3 & 21.6 & 13.5 & 19.0 \\
\hline 4 & & $\begin{array}{l}\text { Staphylococcus } \\
\text { aureus } \\
\text { (MTCC 3160) }\end{array}$ & 12.0 & 14.0 & 14.0 & 23.0 & 25.6 & 24.0 & 26.0 & 16.5 & 19.3 \\
\hline 5 & & $\begin{array}{l}\text { Enterococcus Sp } \\
\text { (MTCC 9728) }\end{array}$ & 11.0 & 12.0 & 15.6 & 20.6 & 25.6 & 23.3 & 25.6 & 17.0 & 18.3 \\
\hline
\end{tabular}

Values are mean $n=3$

The antibiotics were loaded with biosynthesized silver nanoparticles which showed enhancement in their zone of inhibition when compared with AgNPs loaded on the sterile disc. Among the different bacterial samples investigated, Klebsiella pneumoniae pronounced to be effective against the antibiotic tetracycline with highest zone of inhibition followed by Staphylococcus aureus, Enterococcus Sp., Escherichia coli and Bacillus cereus. Interestingly, in the present study, the antibiotic potentiality proved to be varied and enhancement of zone against different gram positive and gram negative microorganisms based on the potentiality of antibiotics was noted. The antibacterial efficacy of synthesized AgNPs enhances because the use of silver and E. crassipes as silver reduced in nano form which increases its surface area, thus make AgNPs more reactive and $E$. crassipes may be enhanced the therapeutic efficacy of AgNPs due to its good antibacterial efficacy. Nano crystalline silver shows the most effective inhibitory action with a rapid inhibition rate (Wright et al., 1998). The activity of antibiotics was enhanced with observable effect against all the microbes tested when combined to silver nanoparticles which might be due to synergistic effect. Similar studies were reported on synergistic action 
for the antibiotic, Levofloxacin with silver nanoparticles against different types of microorganisms and observed to have enhancement due to synergism (Haytham, 2015).

\section{Conclusion}

The results obtained in the present study reveals that silver nanoparticles synthesized biologically from Eichhornia crassipes could be a source of antibacterial activity which can be used to combat the diseases in future. Moreover, the weed can be utilized effectively to a valuable one.

\section{Acknowledgements}

The author would like to express his sincere thanks to UGC-SERO, Hyderabad for the financial assistance (Ref. MRP $5059 / 14)$.

\section{References}

Ahmed Z, Khan SS, Khan, M, Tanveer A, and Ahmad Lone Z. 2009. Synergistic effect of Salvadora persica extracts, tetracycline and penicillin against Staphylococcus aureus. Afr. J. Basic App. Sci.; 2:25-29.

AshaRani, PV., Mun, GLK., Hande, MP., and Valiyaveettil, S. 2009. Cytotoxicity and genotoxicity of silver nanoparticles in human cells. ACS Nano, 3, 279-290.

Bauer AW Kirby S. Herris JC, Turck M 1966. Antibiotic susceptibility testing by a standard disk method. Amer. J. Clin. Path. 45, 493-496.

Chopra, I. 2007. The increasing use of silver-based products as antimicrobial agents: a useful development or a cause for concern? J. Antimicrob. Chemother. 59:587-90.

David, R., Karandikar B., Bonn-Savage N., Bruce G. and Jean-Baptiste R. 2008. Antimicrobial surface functionalization of plastic catheters by silver nanoparticles, J. Antimicr. Chemother.; 61(4):869-876.

Elechiguerra, J., Lui Burt Justin, L., Morones Jose, R., Camacho, B., Alejandra, Xiaoxia Gao, Humberto, $\mathrm{H}$. and Lare, Jose Y Miguel 2005. Interaction of silver nanoparticles with HIV-1. J. Nanobiotech., 3: 1-10.

Gemmell, CG., Edwards, DI., Frainse AP. 2006. Guidelines for the prophylaxis and treatment of methicillin-resistant Staphylococcus aureus (MRSA) infections in the UK. J. Antimicrob. Chemother. 57:589-608.

Haytham MM. Ibrahim. 2015. Green synthesis and characterization of silver nanoparticles using banana peel extract and their antimicrobial activity against representative microorganisms. J. Rad. Res. Appl. Sci. 8: 265-275.

James L., JO Evans, 1991. Noxious Range Weeds. Westview Press, Boulder, CO., USA., p. 466.

Kvitek L., Panacek A., Soukupova J., Kolar M., Vecerova R., Prucek R., Holecova M. and Zboril R. 2008. Effect of Surfactants and Polymers on Stability and Antibacterial Activity of Silver Nanoparticles (NPs). J. Phys. Chem; 112(15):5825-5834.

Liu, JY., Sonshine, DA., Shervani, S., and Hurt, RH 2010. Controlled release of biologically active silver from nanosilver surfaces. ACS Nano, 4, 6903-6913.

Marambio-Jones, C., and Hoek, EMV 2010. A review of the antibacterial effects of silver nanomaterials and potential implications for human health and the environment. J. Nanoparticle Res., 12, 1531-1551.

Nel AE., Madler L., Velegol D., Xia T., Hoek EMV. and Somasundaran P. 2009. Understanding biophysicochemical interactions at the nano-bio interface. Nature Mat., 8, 543-557.

Purushotham KG, Arun P, Jayarani JJ, Vasnthakumari R, Sankar L and Reddy BR. 2010. Synergistic in vitro antibacterial activity of Tectona grandis leaves with tetracycline. Int. J. PharmTech. Res., 2: 519-523.

Russell AD and Hugo WB 1994. Antimicrobial activity and action of silver nanoparticle. J. Nanosci. Nanotect., 31: 351-370.

Raveendran P, Fu J and Wallen SL 2003. Green synthesis and stabilization of 
metal nanoparticles. J. Amer. Chem. Soc., 125:13940-13949.

Sarkar A, Kumar KA, Dutta NK, Chakraborty P, Dastidar SG.2003. Evaluation of in vitro and in vivo antibacterial activity of dobutamine hydrochloride. Ind J. Med. Microbiol., 21:172-178.

Thangapandiyan 2016. Microbial mediated silver nanoparticles by Pseudomonas aeruginosa and their potent antibacterial activity in combination with commercial antibiotics. World J. Pharm. Pharmaceuticals Sci., 5 (3): 703-714. 